Int. J. Dev. Biol. 57: 639-650 (2013)

doi: $10.1387 / \mathrm{ijdb} .130205 \mathrm{av}$

\title{
From Agrobacterium to viral vectors: genome modification of plant cells by rare cutting restriction enzymes
}

\author{
IRA MARTON ${ }^{1}$, ARIK HONIG ${ }^{1}$, AYELET OMID ${ }^{1}$, NOAM DE COSTA ${ }^{1}$, ELENA MARHEVKA ${ }^{1}$, BARRY COHEN ${ }^{1}$ \\ AMIR ZUKER ${ }^{1}$ and ALEXANDER VAINSTEIN*,2 \\ ${ }^{1}$ Danziger Innovations Ltd., Mishmar Hashiva Village, Beit Dagan, Israel and \\ ${ }^{2}$ Institute of Plant Sciences and Genetics in Agriculture, The Robert H. Smith Faculty of Agriculture, Food and Environment, \\ The Hebrew University of Jerusalem, Rehovot, Israel
}

\begin{abstract}
Researchers and biotechnologists require methods to accurately modify the genome of higher eukaryotic cells. Such modifications include, but are not limited to, site-specific mutagenesis, site-specific insertion of foreign DNA, and replacement and deletion of native sequences. Accurate genome modifications in plant species have been rather limited, with only a handful of plant species and genes being modified through the use of early genome-editing techniques. The development of rare-cutting restriction enzymes as a tool for the induction of site-specific genomic double-strand breaks and their introduction as a reliable tool for genome modification in animals, animal cells and human cell lines have paved the way for the adaptation of rare-cutting restriction enzymes to genome editing in plant cells. Indeed, the number of plant species and genes which have been successfully edited using zinc finger nucleases (ZFNs), transcription activator-like effector nucleases (TALENs) and engineered homing endonucleases is on the rise. In our review, we discuss the basics of rare-cutting restriction enzyme-mediated genome-editing technology with an emphasis on its application in plant species.
\end{abstract}

KEY WORDS: genome editing, homing endonucleases, TALENs, viral vectors, ZFNS

\section{Introduction}

The discovery that Agrobacterium can genetically transform plant cells by delivering part of its own genome into those cells led to radical changes in modern agriculture and brought about the era of plant biotechnology and plant genetic engineering (Shiboleth and Tzfira, 2011). In the last three decades, we have witnessed a significant increase in the number of plant species that have been genetically transformed by Agrobacterium or other means. Moreover, the number and variety of traits that have been introduced into crop plants, flowers and forest trees is constantly on the rise and genetically engineered plants are commercially grown on several continents in a growing number of countries. Nevertheless, genetically engineered plants (commonly referred to as genetically modified plants or transgenic plants) have been the subject of much controversy and strong opposition in various countries, most belonging to the European Union. Much of the resistance to genetically modified plants derives from social and political objections to the concept of genetic engineering. However, scientists, policy-makers and environmentalists have also raised concerns about the use of antibiotic-based selection markers in plant genetic transformation, the possible flow of foreign genes to wild species and the nature of the transformation process, which leads to random integration of foreign DNA into the plant cell genome and does not always permit predicting the foreign gene's behavior during the plant's life cycle or across several generations (Fig. 1). Thus, researchers and plant biotechnologists have long sought ways to control the transformation process, and in particular, ways to accurately manipulate the plant genome by means of gene targeting.

Gene targeting by homologous recombination (HR) was originally developed for genome manipulation in yeast (Saccharomyces cerevisiae) cells. This technique requires that the target (acceptor) genomic sequence and the replacement (donor) foreign DNA sequence share a certain homology. Gene targeting by HR also relies on the active participation of the cell's HR DNA-repair

Abbreviations used in this paper: DSB, double strand break; HR, homologous recombination; TALEN transcription activator-like effector nuclease; VAGE, virus-aided gene expression; $\mathrm{ZFN}$, zinc finger nuclease.

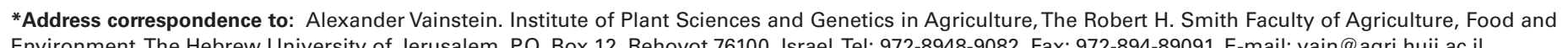
Environment, The Hebrew University of Jerusalem, P.O. Box 12, Rehovot 76100, Israel. Tel: 972-8948-9082. Fax: 972-894-89091. E-mail: vain@agri.huji.ac.il

Final, author-corrected PDF published online: 14 October 2013.

ISSN: Online 1696-3547, Print 0214-6282 
machinery in directing the donor DNA molecules to the target site where they can replace the acceptor sequence. The impact of gene-targeting technology on yeast research prompted scientists to adapt HR-mediated gene-replacement strategy for genome editing in several other model organisms - mouse embryonic stem cells, various fungal species, Physcomitrella patens, Drosophila Melanogaster and several human cell lines. On the other hand, HR-mediated gene replacement in plant species was limited to just a few examples (Table 1), mainly because foreign DNA molecules, which are often delivered by Agrobacterium-mediated gene transfer, integrate at random locations across the target plant genome via non-homologous end joining (NHEJ) and not HR (Lieberman-Lazarovich and Levy, 2011). Early gene-replacement experiments in plants focused on tedious screening methods for the detection of HR-mediated integration events, developing unique and sophisticated transformation vectors and selection methods, and genetic manipulation of the plant's DNA-repair machinery, as we describe below. These approaches met with limited success in developing plants with engineered genomes and novel traits, and biotechnologists continue to search for more reliable, efficient and reproducible methods for genome editing in plant cells (Weinthal et al., 2010; Tzfira et al., 2012).

Genomic double-strand breaks (DSBs), which occur naturally at different stages of plant development and in the life cycle of every cell, can lead to site-specific mutagenesis and can negatively affect genome stability. Thus, genomic DSBs in plants and other organisms are often repaired by the cell's HR DNA-repair machinery to maintain the integrity of their genome. In fact, HR-mediated DNA repair is often enhanced in response to naturally occurring and induced genomic DSBs. Researchers therefore speculated that induction of DSBs at specific locations may lead to enhancement in HR-mediated gene-targeting events, and sought ways of controlling the induction of genomic DSBs at specific locations. Early studies focused on analyzing and studying the effects of
DSBs on the plant DNA-repair pathway, using transgenic plants engineered to carry recognition sites for naturally occurring rarecutting restriction enzymes (e.g. Puchta et al., 1993). Those studies demonstrated that induction of DSBs by expression of naturally occurring rare-cutting restriction enzymes can indeed increase HR-mediated genomic repair at specific genomic locations. In addition, studies have shown that artificially induced genomic DSBs can also act as "traps" for foreign DNA molecules in plant cells (Salomon and Puchta, 1998; Chilton and Que, 2003; Tzfira et al., 2003). Researchers therefore suggested that devising methods for the induction of genomic DSBs in native target sequences by expressing restriction enzymes might lead to the development of reliable gene-targeting methods for plant cells which could also be used for accurate engineering of crop and model plants.

The main bottleneck in the development of restriction enzyme-based targeting methods was the limited repertoire of naturally occurring rare-cutting restriction enzymes (also known as meganucleases) and the technical difficulties involved in reengineering such enzymes for novel specificities (Arnould et al., 2011; Stoddard, 2011; Taylor et al., 2012). A major breakthrough in the implementation of rare-cutting restriction enzyme-based targeting methods for genome editing in plants was made with the development of zinc finger nucleases (ZFNs)-engineered rare-cutting restriction enzymes which were first used for genome editing in human cells (Urnov et al., 2005). Since that pioneering report, engineered rare-cutting restriction enzymes have been used for various genomic-engineering applications in animals, animal cells and human cells, including site-specific mutagenesis, gene replacement by $\mathrm{HR}$, site-specific integration and chromosomal deletion (Urnov et al., 2005; Lee et al., 2010; Takasu et al., 2010; Moehle et al., 2007). ZFNs were soon followed by another type of rare-cutting restriction enzyme, dubbed TALENs (transcription activator-like effector nucleases). These enzymes were also proven useful for genome engineering in animals, animal cells and human

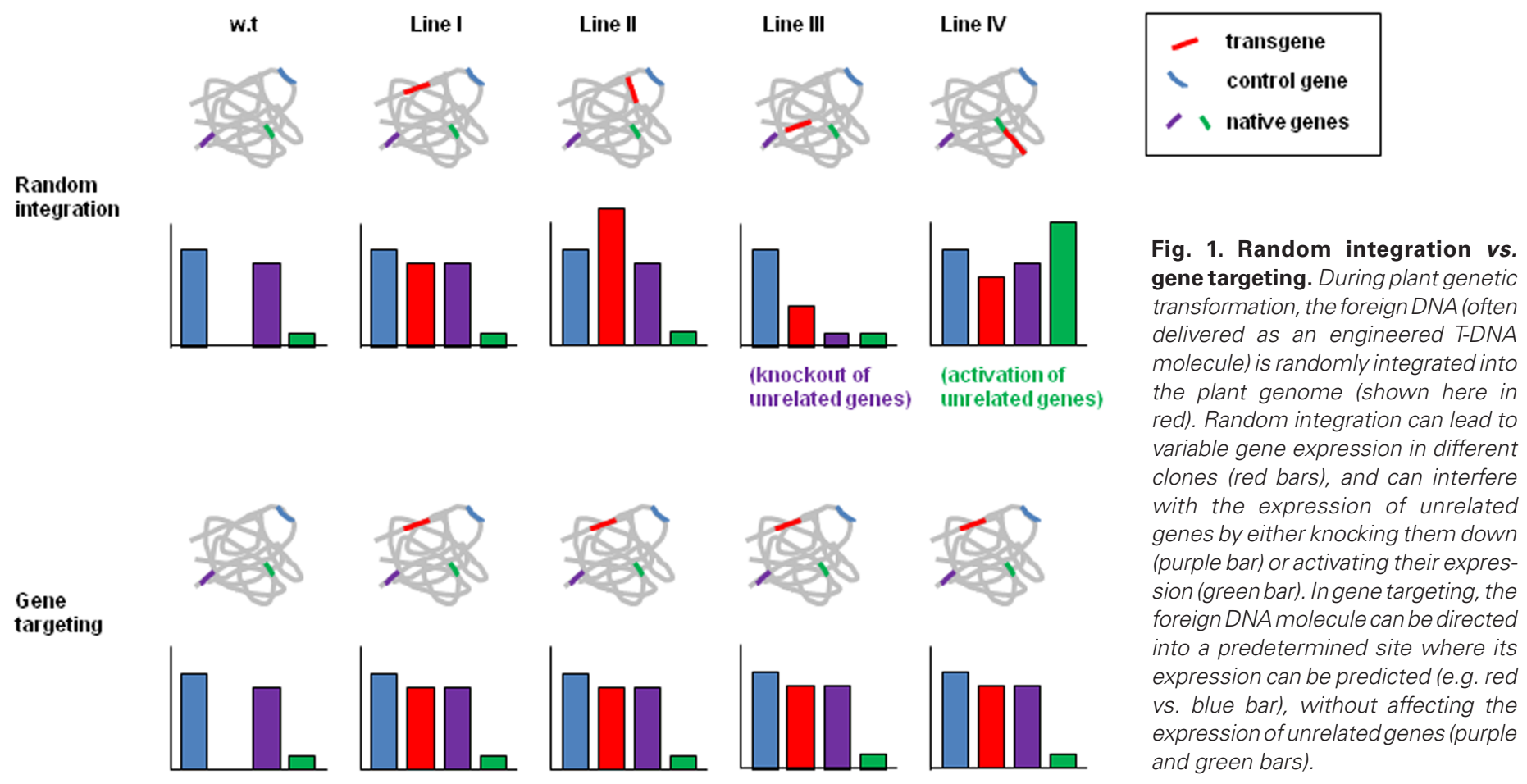


TABLE 1

EXAMPLES OF HOMOLOGOUS RECOMBINATION-MEDIATED GENE REPLACEMENT IN MODEL AND CROP PLANTS

\begin{tabular}{|c|c|c|c|}
\hline Species & Target gene & Outcome & References \\
\hline Tobacco & $\begin{array}{l}\text { Defective APH( }\left(3^{\prime}\right) \| I \\
\text { Defective APH3'II } \\
\text { Sur }\end{array}$ & $\begin{array}{l}\text { Restoration of kanamycin resistance } \\
\text { Restoration of kanamycin resistance } \\
\text { Acquired resistance to chlorsulfuron }\end{array}$ & $\begin{array}{l}\text { Paszkowski et al., } 1988 \\
\text { Offringa et al., } 1990 \\
\text { Lee et al., } 1990\end{array}$ \\
\hline Arabidopsis & $\begin{array}{l}\text { Defective hpt } \\
\text { TGA3 } \\
\text { AGL5 } \\
\text { CHS } \\
\text { PPO } \\
\text { ADH } \\
\text { CRUCIFERIN } \\
\text { CRUCIFERIN }\end{array}$ & $\begin{array}{l}\text { Restoration of hygromycin resistance } \\
\text { Gene replacement } \\
\text { Gene replacement } \\
\text { Mutagenesis } \\
\text { Gene replacement } \\
\text { Gene replacement } \\
\text { Gene replacement } \\
\text { Gene replacement }\end{array}$ & $\begin{array}{l}\text { Halfter et al., } 1992 \\
\text { Miao and Lam, } 1995 \\
\text { Kempin et al., } 1997 \\
\text { Gallego et al., } 1999 \\
\text { Hanin et al., } 2001 \\
\text { Xiaohui Wang et al., } 2001 \\
\text { Shaked et al., 2005 } \\
\text { Even-Faitelson et al., } 2011\end{array}$ \\
\hline Rice & $\begin{array}{l}\text { Sur } \\
\text { Wx } \\
\text { ADH2 } \\
\text { MET1a } \\
\text { Waxy } \\
\text { B1,2-xylosyltransferase } \\
\text { OsIRE1 }\end{array}$ & $\begin{array}{l}\text { Gene replacement } \\
\text { Gene replacement } \\
\text { Gene replacement } \\
\text { Gene replacement } \\
\text { Gene replacement } \\
\text { Gene replacement } \\
\text { Gene replacement }\end{array}$ & $\begin{array}{l}\text { Endo et al., } 2007 \\
\text { Terada et al., } 2002 \\
\text { Terada et al., } 2007 \\
\text { Yamauchi et al., } 2009 \\
\text { Ozawa et al., } 2012 \\
\text { Ozawa et al., } 2012 \\
\text { Wakasa et al., } 2012\end{array}$ \\
\hline Lotus & Gln1, Pzf & Gene replacement & Thykjaer et al., 1997 \\
\hline
\end{tabular}

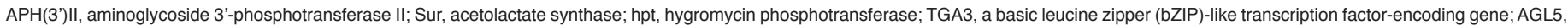

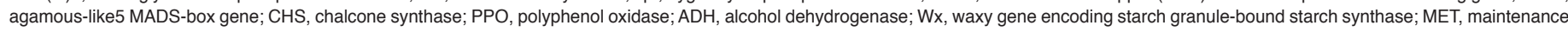

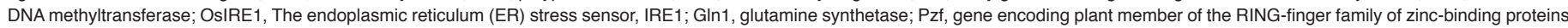

cells (e.g. Lei et al., 2012; Sakuma et al., 2013). More recently, a unique method enabling the simultaneous targeting of multiple sites across the genome has been developed. The method is based on an engineered type II prokaryotic CRISPR (clustered regularly interspaced short palindromic repeats)/CAS which can be guided to and target specific DNA sequences by short RNA molecules (Cong et al., 2013; Mali et al., 2013). The method has been used to target human and mouse cells and can potentially be adapted for the targeting of other genomes, including plants.

There are various ways in which rare-cutting restriction enzymemediated genome editing can be used in plant biotechnology (Fig. 2). Induction of a site-specific DSB in a target gene can abolish its activity by site-specific mutagenesis. Induction of a site-specific DSB can also lead to gene replacement by $\mathrm{HR}$, enabling biotechnolo- gists to replace and manipulate existing alleles in plants. Induction of a site-specific DSB can also be harnessed for gene addition at specific genomic locations, which may lead to improved and more stable and predictable expression. Rare-cutting restriction enzymemediated genome editing can also be used for gene deletion and chromosomal engineering (Fig. 2).

In the past several years, various reviews have been published describing and analyzing many aspects of rare-cutting restriction enzyme-mediated genome modification technology. Most of these reviews have focused on the tremendous progress made in harnessing this unique technology for basic research in animals, animal cells and human cells, and its potential for gene therapy (Urnov et al., 2010). In our review, we focus on the use of rare-cutting restriction enzyme-mediated genome modification in plants. We describe

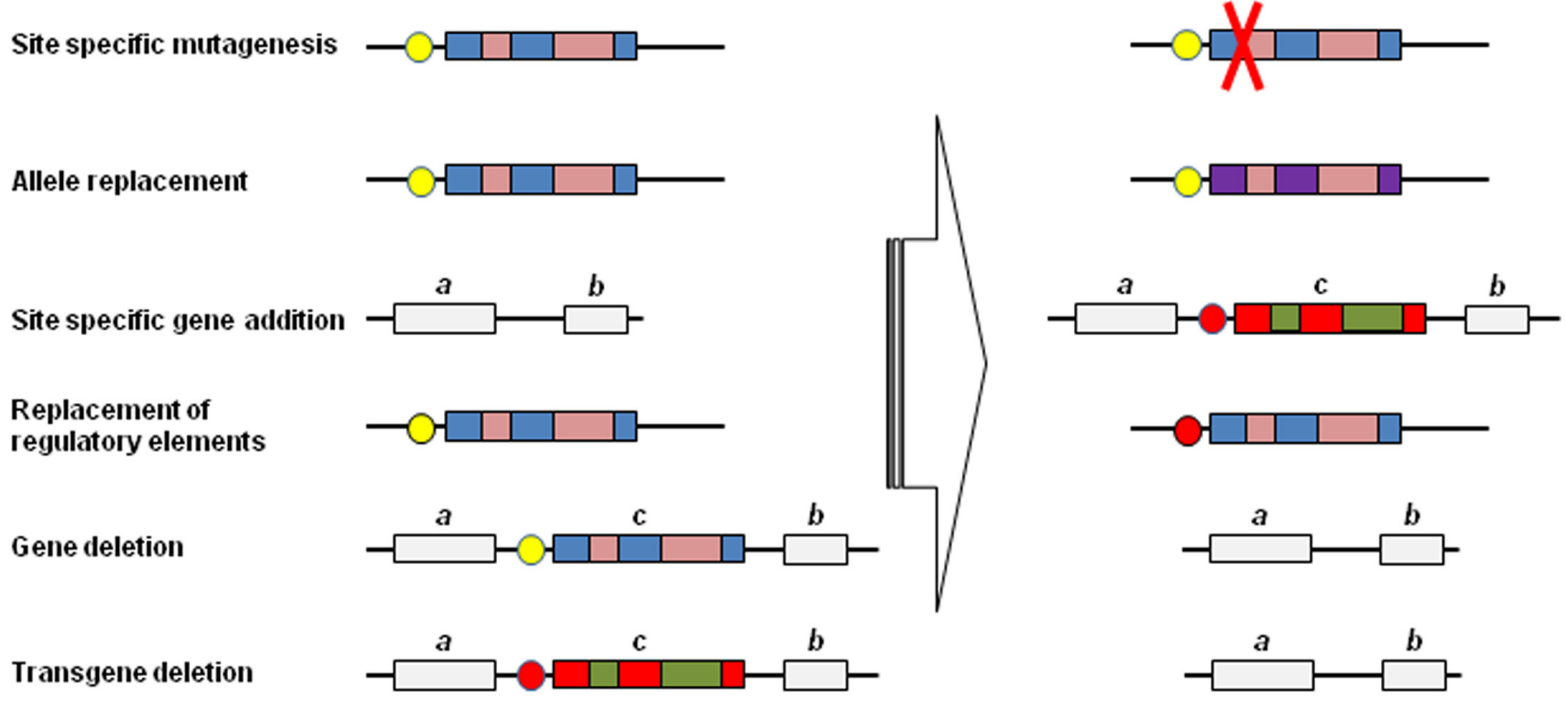

Fig. 2. Applications of genome editing in plant cells. Genome editing can be used for various applications, including-but not limited to-interference with gene activity by site-specific mutagenesis, replacement of existing alleles with engineered or improved ones, addition of new transgenes to predetermined genomic locations, alteration of native gene expression by replacement of regulatory sequences, deletion of native genes or transgenic sequences. Blue and purple bars: exons of native genes; brown bar: intron of native gene; yellow circle: native promoter; red bar, exon of transgenic gene; green bar, intron of transgenic gene; red circle, transgenic promoter. 
the basis for this technology, the type of enzymes used today for induction of genomic DSBs, the tools and procedures developed for rare-cutting restriction enzyme expression in plant cells, and examples of successful applications of this technology in genome modification of transgenic and native sequences in plant cells.

\section{Gene editing by homologous recombination-a brief overview}

Genome targeting in plant cells is not a new concept; over two decades ago, Paszkowski et al., (1988) reported that DNA molecules can integrate into the plant genome via HR and not only via NHEJ. Since HR-mediated gene insertions are rare events, Paszkowski et al., (1988) developed a selection-based method to detect them. In this system, the acceptor locus was a mutated, nonfunctional, kanamycin resistance-encoding gene (aminoglycoside 3'-phosphotransferase) which was transformed into the genome of tobacco plants. As donor DNA, the authors used plasmid DNA which had been linearized and coded for a repair fragment for the defective kanamycin resistance-encoding gene. Kanamycinresistant plants could thus be recovered upon HR-mediated gene correction of the mutated and randomly integrated aminoglycoside 3'-phosphotransferase-encoding gene. Offringa et al., (1990) used Agrobacterium T-DNA molecules and targeted a mutated aminoglycoside 3'-phosphotransferase-encoding gene in transgenic tobacco plants. The targeting of transgenic sequences was next extended to native sequences, as Lee et al., (1990) targeted the SurA and SurB genes in tobacco. Genome editing by HR was not limited to selection genes and Miao and Lam (1995) targeted the TGA3 (a basic leucine zipper-like transcription factor) locus in Arabidopsis using a unique vector engineered to carry a kanamycin-resistance gene placed between two regions homologous to the TGA3 genomic sequence and a GUS-expression cassette which was placed outside the region of homology. This experimental system enabled the selection of either targeted or non-targeted calluses by kanamycin resistance and discriminating between non-targeted (GUS-positive) and targeted (GUS-negative) calluses. Similarly, Kempin et al., (1997) targeted the AGL5 MADS-box gene in Arabidopsis, Hanin et al., (2001) targeted the protoporphyrinogen oxidase-encoding gene in Arabidopsis and Endo et al., (2007) targeted an ALS (acetolactate synthase)-encoding gene in rice. Overall, relying on the cell's natural HR DNA-repair pathway was shown feasible (Table 1 ), but the frequency of targeting was very low and the selection of recombination events was tedious and difficult.

Two different approaches have been taken to overcome the low natural frequency of HR-mediated gene targeting in plants. The first calls for modulating the plant's DNA-repair pathway by expressing heterologous or native DNA-repair genes or by interfering with the function of native DNA-repair genes (Table 1). Reiss et al., (2000) produced RecA-overexpressing transgenic tobacco plants and demonstrated that this key bacterial recombination protein can indeed affect sister chromatid exchange. However, this protein did not enhance HR-mediated gene targeting in the transgenic plants. Increased intrachromosomal and extrachromosomal recombination was also observed in plants overexpressing RuvC (a bacterial protein involved in resolving Holliday junctions) (Shalev et al., 1999), but the effect of this protein on gene targeting was not determined. In other reports, MIM [hypersensitive to methyl methanesulfonate (MMS), irradiation and mitomycin C] mutant plants and MIM-overexpressing plants exhibited decreased and increased intrachromosomal $\mathrm{HR}$ recombination rates, respectively (Mengiste et al., 1999), and plants mutated in rad50 and CAF-1 (chromatin assembly factor) exhibited increased intrachromosomal HR rates (Gherbi et al., 2001; Endo et al., 2006). The possible effect of these proteins on gene targeting in plant cells still needs to be studied. More recently, overexpression of RAD54 (a chromatin-remodeling gene) from yeast in Arabidopsis plants was shown to significantly improve the rate of HR-mediated gene targeting (Shaked et al., 2005; Even-Faitelson et al., 2011).

The second approach adopted to address the low frequency of HR in plant cells was to develop novel transformation vectors which enable discriminating between random and site-specific integration events. The method, dubbed positive-negative selection scheme, depended on the use of two selection markers: one for the detection of all successful integration events (positive selection gene) and the other for the elimination of random integration events (negative selection gene). The system was deployed by Thykjaer et al., (1997), who used a combination of nptll and $\operatorname{cod} A$ genes for positive and negative selection, respectively, for the targeting of Gln1 and Pzf in lotus plants (Table 1) and by Xiaohui et al., (2001), who used the combination of $h t p$ and codA genes to target the alcohol dehydrogenase (ADH)-encoding gene in Arabidopsis. Positive-negative transformation vectors have been proven viable for genome editing of crop and not just model plants. Terada et al., (2002) were the first to report on efficient gene replacement in rice plants, using a combination of hygromycin-resistance and DT-A (Diphtheria toxin A) fragment-encoding genes. In successive reports, the ADH2-encoding gene (Terada et al., 2007), the MET1a promoter (Yamauchi et al., 2009) and the OsIRE1 locus (Wakasa et al., 2012) were also targeted in rice (Table 1). The latter enabled investigating the endoplasmic reticulum in cellular signaling in rice, by replacing the native sequence with two different types of missense alleles, thus demonstrating the importance and suitability of this system for plant research (Wakasa et al., 2012). One clear advantage of the positive-negative selection method is that it can potentially be easily adapted to plant species for which a transformation system has been developed. We have yet to witness the development of additional types of transformation vectors and the expansion of this approach to other plant species.

The two main approaches discussed above, i.e. modulating the plant's DNA-repair mechanisms and the use of novel transformation vectors and selection schemes, have enabled the production of various targeted plants (Table 1). Yet, as discussed in various reviews (e.g. Hohn and Puchta, 1999; Puchta, 2003; Weinthal etal., 2010; Vainstein et al., 2011; Tzfira et al., 2012), gene targeting in plants cells is still considered an art form which is far from routine.

\section{Stimulation of the DNA-repair machinery by induction of genomic DSBs}

Genomic DSBs, which can occur during the lifetime of virtually every living cell, can be repaired by two main mechanisms: HR and NHEJ. When corrected by HR, the native gene can be replaced by sister chromatids, while preserving the accuracy and integrity of the genome. DSB repair by NHEJ, on the other hand, is subject to higher error rates and often results in nucleotide changes, replacement and even deletions at the corrected break site. Studies have shown that to maintain their genome accuracy, cells typically respond to DSB 
induction by activating their HR mechanisms. Indeed, induction of DNA damage by physical (e.g. X-ray) or biological (e.g. excision of transposable elements) means can enhance intrachromosomal HR in plant cells (Tovar and Lichtenstein, 1992; Xiao and Peterson, 2000). More importantly, expression of endonucleases (e.g. $\mathrm{HO}$ and I-Scel) has also been shown capable of inducing DSBs and enhancing intrachromosomal and extrachromosomal HR in plant cells (Chiurazzi et al., 1996; Orel et al., 2003). Naturally, induction of DSBs by endonucleases (e.g. I-Scel or I-Ceul) also leads to site-specific mutagenesis, most likely by NHEJ-mediated repair of the break sites as shown, for example, by Salomon and Puchta (1998); however more importantly, it also leads to NHEJmediated capture of foreign DNA molecules in the break sites (Salomon and Puchta, 1998; Chilton and Que, 2003; Tzfira et al., 2003). Thus, it was shown that in principle, expression of restriction enzymes can lead to a variety of genomic modifications in plant cells and be harnessed for various applications, as exemplified in Fig. 2. The materialization of this concept and its application for targeting native genes in various plant species and for different biotechnological applications were made possible only after the development of ZFNs and other types of rare-cutting restriction enzymes as reagents for site-specific induction of genomic DSBs (Weinthal et al., 2010; Vainstein et al., 2011; Curtin et al., 2012; Tzfira et al., 2012).

\section{Induction of genomic DSBs - enzymes and assays}

The development of rare-cutting restriction enzymes paralleled that of experimental approaches to analyze their activity and tools for their delivery into target cells and tissues. Both stable and transient expression systems have been used for the delivery of rare-cutting restriction enzymes into target cells, and optimal delivery and expression levels of the enzyme have been suggested to be critical for efficient targeting in plants. Those who wish to adapt rare-cutting restricting enzymes to genome editing in plant cells can potentially select from three different types of restriction enzyme: homing endonucleases, ZFNs and TALENs. Homing endonucleases recognize only a few, if any, sites in the genome of various plant species (Hafez and Hausner, 2012). These endonucleases are usually very specific and their use in plant cells has been mostly for the targeting of transgenic sequences (e.g. Puchta, 1998; Salomon and Puchta, 1998; Chilton and Que, 2003; Tzfira et al., 2003; Yang et al., 2009 and Table 2). The main drawback of homing endonucleases is the very small portfolio of natural restriction enzymes and the difficulties involved in re-engineering those enzymes for novel specificities (Arnould et al., 2011). Unlike homing endonucleases, which are naturally occurring rare-cutting restriction enzymes, ZFNs are artificial restriction enzymes. ZFNs consist of a synthetic DNA-binding domain which is fused to the DNA-cleavage domain of the restriction enzyme Fokl (Durai et al., 2005). ZFNs can be artificially designed to recognize extremely long, unique DNA sequences (Durai et al., 2005), and users of this technology can select from various methods for the construction of their rare-cutting restriction enzymes. These include "modular assembly" (Wright et al., 2006; Ramirez et al., 2008), the oligomerized pool engineering (OPEN) strategy (Maeder et al., 2008, 2009) and the context-dependent assembly method (Sander et al., 2011). The development of ZFNs marked the turning point in genome editing of plant cells and many plant species and various genes have been targeted using this technology (Table 2). Similar to ZFNs, TALENs are also artificial restriction enzymes. The DNA-binding domain in TALENs is based on transcription activator-like effectors (Cermak et al., 2011; DeFrancesco, 2011; Hockemeyer et al., 2011; Li et al., 2011b; Mahfouz et al., 2011; Mussolino et al., 2011; Wood et al., 2011) and the cleavage domain is similar to that used in ZFNs, i.e. the DNA-cleavage domain of the restriction enzyme Fokl.

TABLE 2

EXAMPLES OF RESTRICTION ENZYME-MEDIATED GENOME EDITING IN PLANTS

\begin{tabular}{|c|c|c|c|c|}
\hline Species & Target & Enzyme & Outcome & References \\
\hline Tobacco & $\begin{array}{l}\text { Transgene } \\
\text { Transgene } \\
\text { Transgene } \\
\text { Transgene } \\
\text { Transgene } \\
\text { Transgene } \\
\text { Transgene } \\
\text { CHN50 } \\
\text { SuRA, SuRB } \\
\text { Hax3-box }\end{array}$ & $\begin{array}{l}\text { I-Scel } \\
\text { I-Ceul } \\
\text { I-Scel } \\
\text { ZFN } \\
\text { ZFN } \\
\text { ZFN } \\
\text { ZFN } \\
\text { ZFN } \\
\text { ZFN } \\
\text { TALEN }\end{array}$ & $\begin{array}{l}\text { Site-specific NHEJ-mediated integration } \\
\text { NHEJ-mediated integration } \\
\text { NHEJ-mediated integration } \\
\text { Site-specific mutagenesis } \\
\text { Transgene removal } \\
\text { Site-specific mutagenesis } \\
\text { NHEJ-mediated transgene replacement } \\
\text { HR-mediated integration } \\
\text { HR-mediated integration } \\
\text { Site-specific mutagenesis }\end{array}$ & $\begin{array}{l}\text { Salomon and Puchta, } 1998 \\
\text { Chilton and Que, } 2003 \\
\text { Tzfira et al., } 2003 \\
\text { Tovkach et al., } 2009 \\
\text { Petolino et al., } 2010 \\
\text { Marton et al., } 2010 \\
\text { Weinthal et al., } 2013 \\
\text { Cai et al., 2009 } \\
\text { Townsend et al., } 2009 \\
\text { Mahfouz et al., } 2011\end{array}$ \\
\hline BY2 & Transgene & ZFN & HR-mediated integration & Cai et al., 2009 \\
\hline BY2 & CHN50 & ZFN & HR-mediated integration & Cai et al., 2009 \\
\hline Arabidopsis & $\begin{array}{l}\text { Transgene } \\
\text { Transgene } \\
\text { Transgene } \\
\text { Transgene } \\
\text { Transgene } \\
\text { Transgene } \\
\text { ADH1 } \\
A D H 1, T T 4 \\
A B / 4\end{array}$ & $\begin{array}{l}\text { ZFN } \\
\text { ZFN } \\
\text { ZFN } \\
\text { ZFN } \\
\text { ZFN } \\
\text { PB1 } \\
\text { TALEN } \\
\text { ZFN } \\
\text { ZFN }\end{array}$ & $\begin{array}{l}\text { Site-specific mutagenesis } \\
\text { Site-specific mutagenesis } \\
\text { Site-specific mutagenesis } \\
\text { Transgene removal } \\
\text { Site-specific mutagenesis, HR-mediated integration } \\
\text { Transgene removal } \\
\text { Site-specific mutagenesis } \\
\text { Site-specific mutagenesis of two alleles } \\
\text { Site-specific mutagenesis, heritable mutation }\end{array}$ & $\begin{array}{l}\text { Lloyd et al., } 2005 \\
\text { Tovkach et al., } 2009 \\
\text { Even-Faitelson et al., } 2011 \\
\text { Weinthal et al., } 2013 \\
\text { de Pater et al., } 2009 \\
\text { Antunes et al., } 2012 \\
\text { Cermak et al., } 2011 \\
\text { Zhang et al., } 2010 \\
\text { Osakabe et al., } 2010\end{array}$ \\
\hline Maize & $\begin{array}{l}\text { IPK1 } \\
\text { LG1 promoter }\end{array}$ & $\begin{array}{l}\text { ZFN } \\
\text { I-Crel }\end{array}$ & $\begin{array}{l}\text { HR-mediated integration } \\
\text { Site-specific mutagenesis, heritable mutation }\end{array}$ & $\begin{array}{l}\text { Shukla et al., } 2009 \\
\text { Gao et al., } 2010\end{array}$ \\
\hline Petunia & Transgene & ZFN & Site-specific mutagenesis & Marton et al., 2010 \\
\hline \multirow[t]{2}{*}{ Soybean } & Transgene & ZFN & Site-specific mutagenesis & Curtin et al., 2011 \\
\hline & $\begin{array}{l}D C L, R D R, H E N \\
D C L 4 b\end{array}$ & $\begin{array}{l}\text { ZFN } \\
\text { ZFN }\end{array}$ & $\begin{array}{l}\text { Site-specific mutagenesis } \\
\text { Site-specific mutagenesis, heritable mutation }\end{array}$ & $\begin{array}{l}\text { Curtin et al., } 2011 \\
\text { Curtin et al., } 2011\end{array}$ \\
\hline
\end{tabular}

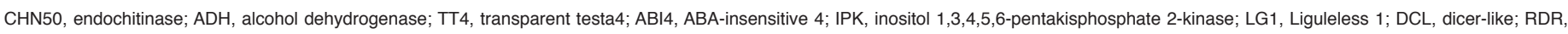
RNA-dependent RNA polymerase; HEN, hua enhancer. 
Here too, users of this technology can employ various methods for engineering and construction of their preferred TALENs ( $\mathrm{Li}$ et al., 2011b; Li and Yang, 2013; Sakuma et al., 2013; Uhde-Stone et al., 2013) or use the design and assembly services of various companies. Similar to ZFNs, TALENs have been quickly adapted for genome engineering of both native and transgenic sequences in various plant species (Table 2). For a further discussion on the design and assembly of rare-cutting restriction enzymes, we refer the readers to the following reviews and research papers: Wright et al., (2006), Maeder et al., (2008, 2009), Ramirez et al., (2008), Cermak et al., (2011), Li et al., (2011b), Mahfouz et al., (2011), Sander et al., (2011), Li and Yang (2013), Sakuma et al., (2013), Uhde-Stone et al., (2013).

With the development of rare-cutting restriction enzymes came the development of various assays to validate and verify their activity. The simplest way to examine the activity of any restriction enzyme is to test whether it can digest its target sequence in vitro while remaining inactive toward non-specific sequences (Mani et al., 2005). Additional assays which validate the activity of rare-cutting restriction enzymes in the context of living cells also exist. The invivo gfp-repair assay, for example, tests the activity of rare-cutting restriction enzymes in the context of chromosomally amended transgenes in mammalian cells by HR-mediated reconstruction of a defective gfp carrying a ZFN target site (Porteus and Baltimore, 2003). This and other reporter-reconstruction-based assays (Doyon et al., 2008; Shukla et al., 2009; Townsend et al., 2009) have been used to validate enzymes used for targeting of the inositol-1,3,4,5,6pentakisphosphate 2-kinase (IPK)-encoding gene IPK1 (Shukla et al., 2009) and the ALS-encoding genes (SuRA and SuRB) (Townsend et al., 2009), as well as for analyses of various TALENs (Christian et al., 2010; Cermak et al., 2011; Li et al., 2011a). Other plant-specific assays have also been developed. Reconstruction of GFP, phosphinothricin N-acetyltransferase, defective NPTII, and GUS have all been used to detect rare-cutting restriction enzyme activity in plants (e.g. Wright et al., 2005; Cai et al., 2009; Shukla et al., 2009; Tovkach et al., 2009). Exemplified in Fig. 3 is one of the assays developed by Tovkach et al., (2009). In this assay, the activity of a rare-cutting restriction enzyme is monitored in living plant cells by activation of a mutated gus gene.

Molecular analysis of targeting events is essential to providing clear and solid evidence of the precision, nature and stability of the targeted genome. One approach relies on PCR analysis of a pool of DNA molecules derived from a targeting experiment in which the transgenic target carries a site for a type-II restriction enzyme (Lloyd et al., 2005). In another approach, the rare-cutting restriction enzyme activity is detected by analysis of fragment polymorphism among DNA fragments which have been amplified, denatured, re-annealed and digested by the endonuclease CEL 1. The assay was originally developed for use in animal and human cell lines and was adapted and modified using the Surveyor nuclease for analysis of experiments targeting the $A B / 4$ gene in Arabidopsis (Osakabe et al., 2010). Naturally, DNA sequencing is highly instrumental for the detection and characterization of targeting events. Pyrosequencing in particular is very useful for the detection of size polymorphism which may derive from sitespecific mutagenesis at the target site, as shown, for example, in targeted tobacco protoplasts and cultured maize cells (Shukla et al., 2009; Townsend et al., 2009).

\section{Induction of genomic DSBs - enzyme expression systems}

Rare-cutting restriction enzyme cassettes can potentially be expressed in target cells using various transformation methods (e.g. Agrobacterium, biolistics and polyethylene glycol). It is important to note that since most ZFNs and TALENs are composed of two distinct monomers, their expression in target cells calls for the use of dual-gene transformation vectors, bicistronic transformation vectors or co-transformation of two independent expression cassettes. Furthermore, in some applications (i.e. gene replacement and gene insertion), another vector, serving as a donor DNA molecule, may also be used. Salomon and Puchta (1998), who were the first to demonstrate the use of rare-cutting restriction enzymes for sitespecific integration, used transient Agrobacterium-mediated genetic transformation for expression of their I-Scel homing endonuclease in plant cells. They observed that the same type of T-DNA molecule (i.e. the T-DNA designed for I-Scel expression) integrated into the DSB site, providing experimental evidence for the applicability of

$\begin{array}{llllll}\mathbf{M} & \mathbf{S} & \mathbf{T} & \mathbf{N} & \mathrm{S} & \star\end{array}$

ATGAGCACCAACTCCTGAGTTGGTGCTTTA. . TACTCGTGGTTGAGGACTCAACCACGAAAT . . . Mutated GUS

\section{NHEJ mediated repair}

$\begin{array}{lllllllll}\text { M } & \text { S } & \text { T } & \text { N } & \text { S } & \text { V } & \text { G } & \text { A } & \text { L }\end{array}$

ATGAGCACCAACTCAGTTGGTGCTTTA. . . TACTCGTGGTTGAGTCAACCACGAAAT . .

Functional GUS

\section{GUS repair assay in plants}
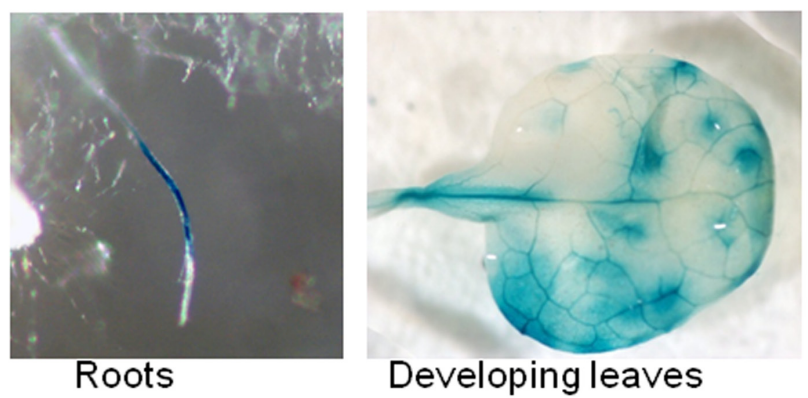

Fig. 3. Restriction enzyme-mediated reporter-gene reconstruction assay in plant cells. The assay enables the detection of restriction enzyme activity in living plant cells and is based on combining a mutated GUSexpression cassette in transgenic tissue or a transgenic plant with transient or stable expression of the restriction enzyme in the plant. Shown here is a partial sequence of the mutated GUS-encoding sequence, in which a stop codon was encoded within the rare-cutting restriction enzyme le.g. ZFN) target site (highlighted in green). Upon cleavage of the target site, the plant's NHEJ repair system can lead to re-activation of a functional GUS-encoding sequence by elimination of the stop codon. When deployed in transgenic plants, expression of the rare-cutting restriction enzyme can be controlled by an inducible promoter (e.g. heat-shock-induced promoter), which enables determining the rare-cutting restriction activity in various cells, tissues and organs during plant development. Panels reproduced from Tovkach et al., (2011). 
this approach to site-specific integration. This approach was later adopted by Chilton and Que (2003) and Tzfira et al., (2003), who used a combination of two T-DNA molecules: one serving as the expression cassette of the homing endonuclease, and the other as a donor T-DNA molecule for site-specific integration experiments in tobacco plants. More recently, Weinthal et al., (2013) used the combination of ZFN expressing T-DNA with a donor, promoterless T-DNA molecule to demonstrate the applicability of this approach for NEHJ-mediated gene replacement in tobacco and Arabidopsis plants. It is worth noting that NHEJ-mediated site-specific T-DNA integration is a relatively efficient process (Tzfira et al., 2003; Weinthal et al., 2013), most likely because the T-DNA is actively directed to genomic DSBs during transformation (Tzfira et al., 2004; Dafny-Yelin et al., 2009). Adapting this approach for NHEJ-mediated gene insertion into native sites and for native gene replacement may require the expression of two distinct ZFN or TALEN monomers. This can be achieved, for example, by using a multigene plant transformation system which has been adapted for co-expression of several ZFN monomers from a single T-DNA molecule (Tovkach et al., 2010).

Co-transformation is also instrumental for HR-mediated genereplacement experiments. Wright et al., (2006), for example, transiently transformed transgenic tobacco protoplast with two plasmids: one which carried a donor DNA and the other, a ZFN-expression cassette. The transgenic tobacco protoplasts were engineered to carry a non-functional reporter gene, which was corrected upon digestion by the ZFN and HR-mediated insertion of the donor DNA. Similarly, Cai et al., (2009) used co-transformation for targeting experiments in BY2 cells, where the donor DNA integrated by HR into specific transgenic (disabled gfp and pat genes) and native (endochitinase gene CHN50) genomic sites. For targeting of the transgenic sequences, the authors used a single ZFN monomerexpression cassette which was co-transformed with a donor DNA molecule. For targeting of the native $\mathrm{CHN50}$, the authors had to deliver two ZFN monomers together with a donor DNA molecule. To this end, $2 A$ sequence was used to separate the sequences of the CHN50 ZFN monomer coding sequences and to deliver them as a single transcript from a single plant expression cassette. The advantage of this approach over the use of dual, independent ZFN-expression cassettes is that it enables maintaining a molar ratio of both ZFN monomers in the transformed cells.

Co-transformation was later adapted for delivery of ZFN monomers in experiments targeting the ALS-encoding genes SURA and SuRB in tobacco (Maeder et al., 2008, 2009), ZFN monomers in targeting experiments in soybean (Curtin et al., 2011), targeting IPK in maize plants (Shukla et al., 2009) and more. In the latter experiments, two different types of donor DNA molecule were constructed. The autonomous donor molecules carried a fully functional selection marker gene (i.e. a pat-expression cassette), while the non-autonomous donor molecules were constructed with a promoterless selection gene. The latter required functional trapping, by HR, of the pat reporter gene by the IPK promoter and resulted in a higher number of HR-mediated targeting events than with the autonomous donor molecules (Shukla et al., 2009). Worth noting is that transformed calluses derived from random integration events carried multiple insertions across their genome, while targeted calluses often contained a single insertion event, derived from HR-mediated gene replacement. Since foreign DNA molecules may be actively directed to genomic DSBs (Tzfira et al.,
2004; Dafny-Yelin et al., 2009), we suggest that random integration events derived from cells which were genetically transformed by donor and not by ZFN-expressing DNA. Alternatively, if the transformation of both ZFN-expressing DNA and donor DNA occurred at the same efficiencies, the ZFN expression levels might not have been sufficient to produce long-lived DSB sites.

A possible solution to overcoming the low expression levels of rare-cutting restriction enzymes in target cells is to use a transgenic approach for their expression. This approach was adopted in the pioneering report of Lloyd et al., (2005), who targeted a transgenic sequence in Arabidopsis plants. More specifically, the authors used a heat-shock promoter to control the expression of their ZFNs in transgenic Arabidopsis plants. Induction of 10-dayold plants resulted in the development of mutated and chimeric inflorescence stems and molecular analysis revealed that these mutations resulted from site-specific mutagenesis, which most likely occurred in early-stage L2 cells of the shoot apical meristem. Interestingly, only roughly $10 \%$ of the seedlings derived from heatshocked plants were mutated, even though the parental lines were transgenic. Similarly, Tovkach et al., (2009), who adapted the heatshock induction approach in their whole-plant DNA-repair assay, also observed that only a fraction of the transgenic plant cells were mutated, as determined by reconstruction of GUS activity (Fig. 3).

Other types of inducible and constitutive promoters have been used in attempts to increase the gene-targeting rates in transgenic plants. de Pater et al., (2009), for example, used transgenic Arabidopsis plants in which the rare-cutting restriction enzymes (i.e. ZFNs) are stably expressed under the control of the Rps5 tissue-specific, tamoxifen-inducible, and constitutive $35 \mathrm{~S}$ promoters. The plants were also engineered to carry a transgenic target site, composed of functional pat and gfp genes. Interestingly, even when the strong and constitutive 35S promoter was used, only $2 \%$ of the transgenic cells were mutated (de Pater et al., 2009), which led to the suggestion that tissue-specific may be more suitable for HR-mediation-based targeting experiments. Indeed, using donor T-DNA which was designed with homology regions to the transgenic site and Rps5-ZFN-transgenic plants (in which the expressed ZFN is active in early embryonic tissues), de Pater et al., (2009) successfully achieved HR-mediated gene replacement in Arabidopsis plants, albeit at a very low frequency. The importance of expression levels was later demonstrated by Zhang et al., (2010) who used an estrogen-inducible promoter to control the expression of ZFNs designed to target the native $A D H 1$ and TT4 genes in Arabidopsis. The dual dimer ZFNs were expressed from a single transcript, fused to each other by the T2A peptide. Mutated plants were recovered from $17 \beta$-estradiol-induced transgenic plants and relatively high percentages of the plants were mutated in one or two alleles of each gene. The high rates were attributed, in part, to the activity of the $17 \beta$-estradiol promoter, which was reported to be stronger than the constitutive 35 S promoter (Zuo et al., 2000). The $17 \beta$-estradiol-induced promoter was also used in targeting experiments in soybean (Curtin et al., 2011). More specifically, ZFNexpressing transgenic soybean plants were produced and plantlets, in which the DLC4a or DLC4b genes were mutated, were allowed to recover upon addition of $17 \beta$-estradiol during in-vitro culturing. Since these plants were either heterozygous or chimeric for the mutated alleles, they developed and set seed, and homozygous and heterozygous ZFN-free DLC4b mutant lines were recovered. Other types of promoters were used for targeting experiments in 
plants. The strong and constitutive ubiquitin promoter was used in transgenic maize to control the expression of two homing endonuclease I-Crel monomers, designed for targeting of the native LG1 promoter (Gao et al., 2010). The egg-cell-specific promoter EASE was used for site-specific mutagenesis of transgenic sequences in transgenic Arabidopsis plants (Even-Faitelson et al., 2011). The heat-shock-inducible promoter was used for production of mutated abi4 Arabidopsis plants (Osakabe et al., 2010) and the strong 35S promoter was used for deletion of the GUS gene in transgenic tobacco plants (Petolino et al., 2010).

Transient and stable gene-expression systems have been shown useful for targeting different genes in various plant species. It is worth noting, however that in most cases, the expression of rare-cutting restriction enzymes has been limited to one or two monomers, while more complex applications (e.g. deletion of chromosomal fragments, mutation of several closely related alleles or NHEJ-mediated native gene replacements) may call for expression of several monomers. This can be achieved by producing transgenic plants in multiple rounds of transformation (DafnyYelin and Tzfira, 2007; Naqvi et al., 2010), by using polyprotein vectors (Halpin et al., 1999; El Amrani et al., 2004) or multigene vectors (Tovkach et al., 2010). A dedicated plant ZFN-expression system, which enables the expression of up to four independent ZFN monomers, was developed by Tovkach et al., (2009). The system can be easily adapted for transient or stable expression of TALENs or homing endonucleases under the control of various promoters and selection markers.

\section{Virus-aided gene expression (VAGE) and production of non-transgenic targeted plants}

Gene replacement and targeted gene insertion rely on the delivery of donor DNA into plant cells while other applications (e.g. site-specific mutagenesis and gene deletion) depend solely on the expression of rare-cutting restriction enzymes (Fig. 2). Yet, while donor-free targeting applications can potentially yield targeted plants that are free of foreign DNA, these plants may still be classified as transgenic if direct gene-transfer methods were used for expression of the rare-cutting restriction enzymes. In a unique approach, Marton et al., (2010) developed a viral-based expression system for efficient delivery of rare-cutting restriction enzymes to plant cells. VAGE systems, which can be based on DNA or RNA viruses, rely on the virus's ability to replicate, spread from cell to cell and across different tissues and organs, and express genes in all infected cells (Matoba et al., 2011). The system of Marton et al., (2010) makes use of tobacco rattle virus (TRV)-based vectors. Several vectors were designed to facilitate the transport of single- and dual-monomer restriction enzymes from a single or two independent promoters (Fig. 4). The authors demonstrated that transient ZFN expression from such viral vectors can facilitate site-specific mutagenesis in plant cells, as demonstrated by reconstruction of mutated GUS in transgenic tobacco and petunia cells (Fig. 4). The advantages of viral-based vectors over transient and stable gene-transfer methods are numerous. VAGE often results in extremely high protein levels in infected cells. This phenomenon is of particular importance for the expression of rare-cutting restriction enzymes since low expression levels have been suggested to be one of the causes for low targeting efficiency. Thus, for example, the high efficiency of $A D H 1$ and TT4 targeting in Arabidopsis was

attributed, at least in part, to the use of transgenic plants in which ZFN expression was controlled by the strong estrogen-inducible promoter (Zhang et al., 2010). Further modifications to the pTRV vectors, and use of stronger promoters than $\mathrm{sgP}$, may result in even higher levels of rare-cutting restriction enzymes, and perhaps higher gene-targeting rates. TRV-based vectors can simplify the co-delivery of several rare-cutting restriction enzymes into target cells. More specifically, Marton et al., (2010) showed that coinfection of plant cells with two distinct vectors, each designed to carry a different reporter gene, results in expression of both reporters within the same cells. Thus, by using two viral vectors, each with two ZFN monomers, users of this technology can potentially deliver two or even more rare-cutting restriction enzymes into the target cell. It should be noted that pTRV-based vectors have also been found capable of delivering foreign proteins into the plant cell's chloroplasts and mitochondria and can thus potentially be used for genome editing of these organelles, by means of rarecutting restriction enzymes, as demonstrated, for example, in human cells (Minczuk et al., 2008). Third, since viral vectors can travel from cell to cell and systemically infect their host, their use offers a unique strategy which will enable bypassing the need for regeneration of new plants in tissue culture as illustrated in Fig. 5. Indeed, pTRV-based vectors have been reported capable of traveling into a wide range of organs, tissues and cells, including meristems, growing buds, ovules and other flower parts (Vainstein et al., 2011). These vectors can potentially be used for infection of whole plants, leading to the development of mutated meristems,

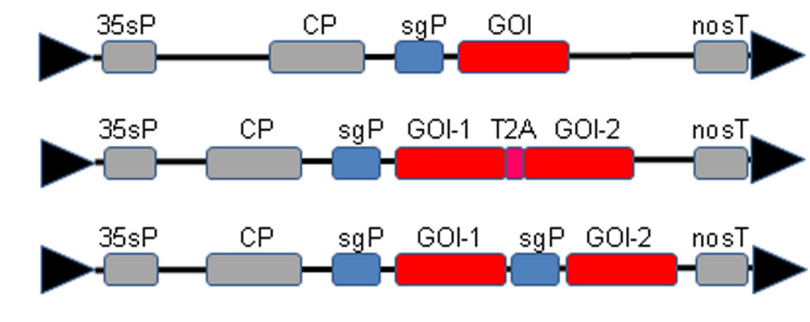

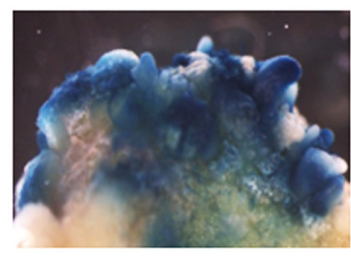

Primordia

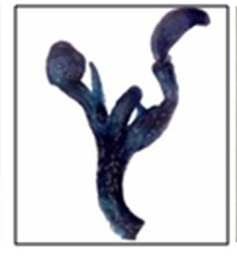

Plantlet

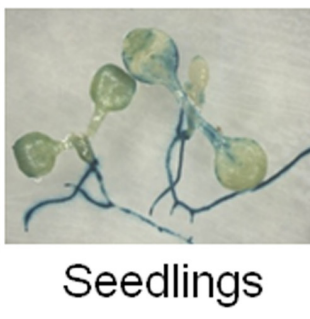

Fig. 4. pTRV-based vectors for expression of rare-cutting restriction enzymes. The vectors were designed to be launched from Agrobacterium binary plasmids as T-DNA molecules. Production of the first viral transcript is mediated by the constitutive 35 S promoter (35sP) and nopaline synthase terminator (nosT). Three different types of plasmids were designed to facilitate the expression of (top) a single gene of interest (GOI) from a single promoter (i.e. the sgP constitutive promoter), (centre), two genes (GOI1 and GOI2) fused together by a T2A sequence from a single promoter, (bottom) two genes (GOI1 and GOI2), from two independent promoters. Image modified from Marton et al., (2010). Infection of mature petunia plants with pTRV-ZFN vectors leads to the regeneration of mutated primordia, from which mutated plantlets can be recovered. The ZFN-mediated mutagenesis remains stable, as determined by GUS expression in seedlings derived from mutated plantlets. Panels reproduced from Marton et al., (2010). 


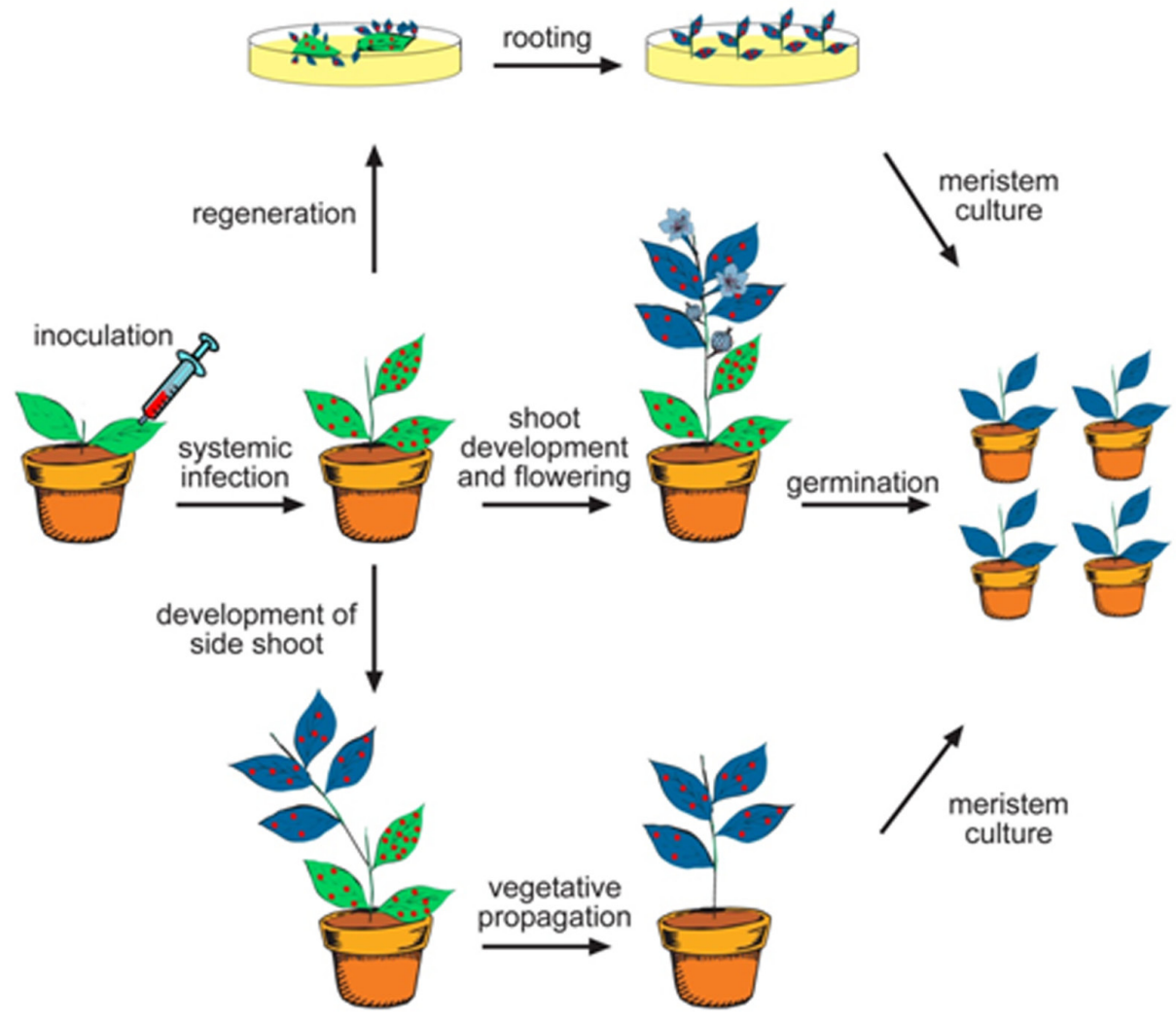

Fig. 5. Non-transgenic genome editing of plant cells by viral vectors. Initial infection of the target plant by direct gene transfer will lead to system infection (shown in red) and development of mutated tissues and organs from existing side shoots (shown in blue, bottom). These side shoots can then be propagated vegetatively, cleaned by meristem culture techniques and developed into virus-free mutated plants. Alternatively, infected leaves can be used as starting material for in-vitro regeneration of mutated meristems (top) from which plantlets can be developed and cleaned. Mutated side shoots can also be allowed to develop, flower and set seed (center). These seeds can then be germinated and develop into virus-free, mutated plants, without the need for tissue-culture steps. Image reproduced from Vainstein et al., (2011) with permission.

gene expression and stable gene expression have been the most useful strategies for the production of mutated plants. Nevertheless, direct gene-transfer methods are likely to render the plant transgenic, placing constraints on its use for agricultural applications. The use of viral-based vectors for efficient non-transgenic production of genome-modified plants has been proven feasible in model (tobacco) and crop (petunia) plants. The use of RNA vectors guaran-

fruits and eventually seeds (Fig. 5).

It is important to note that viral vectors, and in particular pTRV an RNA-based vector-do not integrate into the plant genome and hence the product of viral-mediated genome-edited plants may be classified as non-transgenic. This will likely simplify the introduction of targeted plants into the market. While the application of pTRV vectors for genome editing has been described in petunia and tobacco plants, the ability of this vector to infect a wide range of plant species (Vainstein et al., 2011) suggests that viral-based rare-cutting restriction enzymes can potentially be adapted for genome editing in these plant species.

\section{Future prospects}

Plant genome modification is a novel technology which is likely to follow in the footsteps of transgenic technology and impact the pace of new development in plant biotechnology and agriculture. Tremendous progress has been made in the development of the basic building blocks for this technology (i.e. rare-cutting restriction enzymes) and users can pick and choose from a wide range of systems and protocols for assembly, evaluation and analysis of ZFNs, TALENs, and other types of rare-cutting restriction enzymes (Dreier et al., 2001; Liu et al., 2002; Mani et al., 2005; Arnould et al., 2006; Carroll et al., 2006; Wright et al., 2006; Sander et al., 2007, 2011; Maeder et al., 2008; Cermak et al., 2011; Li et al., 2011b; Ramalingam et al., 2011; Reyon et al., 2011) and the number of plant species whose genome has been modified by such enzymes is on the rise (Table 2).

Several strategies can be deployed for the expression of rarecutting restriction enzymes in plant cells. Among these, transient tees that mutated plants obtained by this technology will be free of any contaminating foreign DNA; they are likely to be classified as non-transgenic and to significantly impact the introduction of rare-cutting restriction enzyme technology into agricultural crops.

\section{Acknowledgements}

A.V. is an incumbent of the Wolfson Chair in Floriculture.

\section{References}

ANTUNES M S, SMITH J J, JANTZ D, MEDFORD J I (2012). Targeted DNA excision in Arabidopsis by a re-engineered homing endonuclease. BMC Biotechnol 12: 86 .

ARNOULD S, CHAMES P, PEREZ C, LACROIX E, DUCLERT A, EPINAT J C STRICHERF, PETITAS, PATINA, GUILLIERS, ROLLAND S, PRIETOJ, BLANCO F J, BRAVO J, MONTOYA G, SERRANO L, DUCHATEAU P, PAQUES F (2006). Engineering of large numbers of highly specific homing endonucleases that induce recombination on novel DNA targets. J Mol Biol 355: 443-458.

ARNOULD S, DELENDA C, GRIZOT S, DESSEAUX C, PAQUES F, SILVA G H, SMITH J (2011). The I-Crel meganuclease and its engineered derivatives: applications from cell modification to gene therapy. Protein Eng Des Sel 24: 27-31.

CAI C Q, DOYON Y, AINLEY W M, MILLER J C, DEKELVER R C, MOEHLE E A, ROCK J M, LEE Y L, GARRISON R, SCHULENBERG L, BLUE R, WORDEN A, BAKER L, FARAJI F, ZHANG L, HOLMES M C, REBAR E J, COLLINGWOOD T N, RUBIN-WILSON B, GREGORY P D, URNOV F D, PETOLINO J F (2009). Targeted transgene integration in plant cells using designed zinc finger nucleases. Plant Mol Biol 69: 699-709.

CERMAKT, DOYLE E L, CHRISTIAN M, WANG L, ZHANG Y, SCHMIDT C, BALLER J A, SOMIA N V, BOGDANOVE A J, VOYTAS D F (2011). Efficient design and assembly of custom TALEN and other TAL effector-based constructs for DNA targeting. Nucleic Acids Res 39: e82.

CHILTON M-D, QUE Q (2003). Targeted integration of T-DNAinto the tobacco genome at double-strand breaks: new insights on the mechanism of T-DNA integration. Plant Physiol 133: 956-965. 
CHIURAZZI M, RAY A, VIRET J F, PERERA R, WANG X H, LLOYD A M, SIGNER E $\mathrm{R}$ (1996). Enhancement of somatic intrachromosomal homologous recombination in Arabidopsis by the $\mathrm{HO}$ endonuclease. Plant Cell 8: 2057-2066.

CHRISTIAN M, CERMAK T, DOYLE E L, SCHMIDT C, ZHANG F, HUMMEL A, BOGDANOVE A J, VOYTAS D F (2010). Targeting DNA double-strand breaks with TAL effector nucleases. Genetics 186: 757-761.

CONG L, RAN FA, COX D, LIN S, BARRETTO R, HABIB N, HSU P D, WU X, JIANG W, MARRAFFINI L A, ZHANG $F$ (2013). Multiplex genome engineering using CRISPR/Cas systems. Science 339: 819-823.

CURTIN S J, VOYTAS D F, STUPARA R M (2012). Genome engineering of crops with designer nucleases. Plant Genome 5: 42-50.

CURTIN S J, ZHANG F, SANDER J D, HAUN W J, STARKER C, BALTES N J, REYON D, DAHLBORG E J, GOODWIN M J, COFFMAN A P, DOBBS D, JOUNG J K, VOYTAS D F, STUPAR R M (2011). Targeted mutagenesis of duplicated genes in soybean with zinc-finger nucleases breakthrough technologies. Plant Physiol 156: 466-473.

DAFNY-YELIN M, TOVKACH A, TZFIRA T (2009). Integration of Agrobacterium TDNA in plant cells. In Functional organization of the plant nucleus (Ed I Meier I). Springer, pp. 157-186.

DAFNY-YELIN M, TZFIRA T (2007). Delivery of multiple transgenes to plant cells. Plant Physiol 145: 1118-1128.

CARROLL D, MORTON J J, BEUMER K J, and SEGAL D J (2006) Design, construction and in vitro testing of zinc finger nucleases. Nature Protocols 1:1329-1341.

DEFRANCESCO L (2011). Move over ZFNs. Nat Biotechnol 29: 681-684.

DE PATER S, NEUTEBOOM L W, PINAS J E, HOOYKAAS P J, VAN DER ZAAL B $\mathrm{J}$ (2009). ZFN-induced mutagenesis and gene-targeting in Arabidopsis through Agrobacterium-mediated floral dip transformation. Plant Biotechnol J7: 821-835.

DOYON Y, MCCAMMON J M, MILLER J C, FARAJI F, NGO C, KATIBAH G E, AMORA R, HOCKING T D, ZHANG L, REBAR E J, GREGORY P D, URNOV F $D, A M A C H E R ~ S L$ (2008). Heritable targeted gene disruption in zebrafish using designed zinc-finger nucleases. Nat Biotechnol 26: 702-708.

DREIER B, BEERLI R R, SEGAL D J, FLIPPIN J D, BARBAS C F 3rd (2001) Development of zinc finger domains for recognition of the 5'-ANN-3' family of DNA sequences and their use in the construction of artificial transcription factors. $J$ Biol Chem 276: 29466-29478.

DURAI S, MANI M, KANDAVELOU K, WU J, PORTEUS M H, CHANDRASEGARAN $S$ (2005). Zinc finger nucleases: custom-designed molecular scissors for genome engineering of plant and mammalian cells. Nucleic Acids Res 33: 5978-5990.

ELAMRANI A, BARAKATEA, ASKARI B M, LIX, ROBERTS A G, RYAN M D, HALPIN $C$ (2004). Coordinate expression and independent subcellular targeting of multiple proteins from a single transgene. Plant Physiol 135: 16-24.

ENDO M, ISHIKAWA Y, OSAKABE K, NAKAYAMAS, KAYA H, ARAKIT, SHIBAHARA K, ABE K, ICHIKAWA H, VALENTINE L, HOHN B, TOKI S (2006). Increased frequency of homologous recombination and T-DNA integration in Arabidopsis CAF-1 mutants. EMBO J 25: 5579-5590.

ENDO M, OSAKABE K, ONO K, HANDA H, SHIMIZU T, TOKI S (2007). Molecular breeding of a novel herbicide-tolerant rice by gene targeting. Plant J 52: 157-166.

EVEN-FAITELSON L, SAMACH A, MELAMED-BESSUDO C, AVIVI-RAGOLSKY N, LEVY A A (2011). Localized egg-cell expression of effector proteins for targeted modification of the Arabidopsis genome. Plant J 68: 929-937.

GALLEGO M E, SIRAND-PUGNET P, WHITE C I (1999). Positive-negative selection and T-DNA stability in Arabidopsis transformation. Plant Mol Biol 39: 83-93.

GAO H, SMITH J, YANG M, JONES S, DJUKANOVIC V, NICHOLSON M G, WEST A, BIDNEY D, FALCO S C, JANTZ D, LYZNIK L A (2010). Heritable targeted mutagenesis in maize using a designed endonuclease. Plant J 61: 176-187.

GHERBI H, GALLEGO ME, JALUT N, LUCHT JM, HOHN B, WHITE C (2001) Homologous recombination in planta is stimulated in the absence of Rad50. EMBO Rep 2: 287-291.

HAFEZ M, HAUSNER G (2012). Homing endonucleases: DNA scissors on a mission. Genome 55: 553-569.

HALFTER U, MORRIS P C, WILLMITZER L (1992). Gene targeting in Arabidopsis Thaliana. Mol Gen Genet 231: 186-193.

HALPIN C, COOKE S E, BARAKATE A, EL AMRANI A, RYAN M D (1999). Selfprocessing 2A-polyproteins-a system for co-ordinate expression of multiple proteins in transgenic plants. Plant $J$ 17: 453-459.
HANIN M, VOLRATH S, BOGUCKI A, BRIKER M, WARD E, PASZKOWSKI J (2001). Gene targeting in Arabidopsis. Plant J 28: 671-677.

HOCKEMEYER D, WANG H, KIANI S, LAI C S, GAO Q, CASSADY J P, COST G J, ZHANG L, SANTIAGO Y, MILLER J C, ZEITLER B, CHERONE J M, MENG $X$, HINKLEY S J, REBAR E J, GREGORY P D, URNOV $F$ D, JAENISCH R (2011). Genetic engineering of human pluripotent cells using TALE nucleases. Nat Biotechnol 29: 731-734.

HOHN B, PUCHTA H (1999). Gene therapy in plants. Proc Natl Acad Sci USA 96: 8321-8323.

KEMPIN S A, LILJEGREN S J, BLOCK L M, ROUNSLEY S D, YANOFSKY M F, LAM E (1997). Targeted disruption in Arabidopsis. Nature 389: 802-803.

LEE H J, KIM E, KIM J S (2010). Targeted chromosomal deletions in human cells using zinc finger nucleases. Genome Res 20: 81-89.

LEE K Y, LUND P, LOWE K, DUNSMUIR P (1990). Homologous recombination in plant cells after Agrobacterium-mediated transformation. Plant Cell 2: 415-425.

LEI Y, GUO X, LIU Y, CAO Y, DENG Y, CHEN X, CHENG C H, DAWID I B, CHEN $\mathrm{Y}, \mathrm{ZHAO} \mathrm{H}$ (2012). Efficient targeted gene disruption in Xenopus embryos using engineered transcription activator-like effector nucleases (TALENs). Proc Natl Acad Sci USA 109: 17484-17489.

LI T, HUANG S, JIANG W Z, WRIGHT D, SPALDING M H, WEEKS D P, YANG B (2011a). TAL nucleases (TALNs): hybrid proteins composed of TAL effectors and Fokl DNA-cleavage domain. Nucleic Acids Res 39: 359-372.

LIT, HUANG S, ZHAO X, WRIGHT D A, CARPENTER S, SPALDING M H, WEEKS D P, YANG B (2011b). Modularly assembled designer TAL effector nucleases for targeted gene knockout and gene replacement in eukaryotes. Nucleic Acids Res.

LI T, YANG B (2013). TAL effector nuclease (TALEN) engineering. Methods Mol Biol 978: 63-72.

LIEBERMAN-LAZAROVICH M, LEVY A A (2011). Homologous recombination in plants: an antireview. Methods Mol Biol 701: 51-65.

LIU Q, XIA Z, ZHONG X, CASE C C (2002) Validated zinc finger protein designs for all 16 GNN DNA triplet targets. J Biol Chem 277:3850-3856.

LLOYD A, PLAISIER C L, CARROLL D, DREWS G N (2005). Targeted mutagenesis using zinc-finger nucleases in Arabidopsis. Proc NatlAcad SciUSA 102:2232-2237.

MAEDER M L, THIBODEAU-BEGANNY S, OSIAK A, WRIGHT D A, ANTHONY R $M$, EICHTINGER M, JIANG T, FOLEY J E, WINFREY R J, TOWNSEND J A, UNGER-WALLACE E, SANDER J D, MULLER-LERCH F, FU F, PEARLBERG J, GOBEL C, DASSIE J P, PRUETT-MILLER S M, PORTEUS M H, SGROI D C, IAFRATE AJ, DOBBS D, MCCRAY P B JR, CATHOMENT, VOYTAS D F, JOUNG JK (2008). Rapid "open-source" engineering of customized zinc-finger nucleases for highly efficient gene modification. Mol Cell 31: 294-301.

MAEDER M L, THIBODEAU-BEGANNY S, SANDER J D, VOYTAS D F, JOUNG J $K$ (2009). Oligomerized pool engineering (OPEN): an 'open-source' protocol for making customized zinc-finger arrays. Nat Protoc 4: 1471-1501.

MAHFOUZ M M, LI L, SHAMIMUZZAMAN M, WIBOWO A, FANG X, ZHU J K (2011). De novo-engineered transcription activator-like effector (TALE) hybrid nuclease with novel DNA binding specificity creates double-strand breaks. Proc Natl Acad Sci USA 108: 2623-2628.

MALI P, YANG L, ESVELT K M, AACH J, GUELL M, DICARLO J E, NORVILLE J E, CHURCH G M (2013). RNA-guided human genome engineering via Cas9. Science 339: 823-826.

MANI M, KANDAVELOU K, DY F J, DURAI S, CHANDRASEGARAN S (2005). Design, engineering, and characterization of zinc finger nucleases. Biochem Biophys Res Commun 335: 447-457.

MARTON I, ZUKER A, SHKLARMAN E, ZEEVI V, TOVKACH A, ROFFE S, OVADIS M, TZFIRA T, VAINSTEIN A (2010). Plant Physiol 154: 1079-1087.

MATOBA N, DAVIS K R, PALMER K E (2011). Recombinant protein expression in Nicotiana. Methods Mol Biol 701: 199-219.

MENGISTE T, REVENKOVA E, BECHTOLD N, PASZKOWSKI J. (1999). An SMClike protein is required for efficient homologous recombination in Arabidopsis. EMBO J 18: 4505-4512.

MIAO Z H, LAM E (1995). Targeted disruption of the TGA3 locus in Arabidopsis Thaliana. Plant J 7: 359-365.

MINCZUKM, PAPWORTH MA, MILLER J C, MURPHY M P, KLUGA (2008). Development of a single-chain, quasi-dimeric zinc-finger nuclease for the selective degradation of mutated human mitochondrial DNA. Nucleic Acids Res 36: 3926-3938. 
MOEHLE E A, ROCK J M, LEE Y L, JOUVENOT Y, DEKELVER R C, GREGORY P D, URNOV F D, HOLMES M C (2007). Targeted gene addition into a specified location in the human genome using designed zinc finger nucleases. Proc Natl Acad Sci USA 104: 3055-3060.

MUSSOLINOC, MORBITZERR, LUTGEF, DANNEMANN N, LAHAYET, CATHOMEN T (2011). A novel TALE nuclease scaffold enables high genome editing activity in combination with low toxicity. Nucleic Acids Res

NAQVI S, FARRE G, SANAHUJA G, CAPELL T, ZHU C, CHRISTOU P (2010). When more is better: multigene engineering in plants. Trends Plant Sci 15: 48-56.

OFFRINGA R, DE GROOT M J, HAAGSMAN H J, DOES M P, VAN DEN ELZEN P J, HOOYKAAS P J (1990). Extrachromosomal homologous recombination and gene targeting in plant cells after Agrobacterium mediated transformation. EMBO J 9: 3077-3084.

OREL N, KYRYK A, PUCHTA H (2003). Different pathways of homologous recombination are used for the repair of double-strand breaks within tandemly arranged sequences in the plant genome. Plant J 35: 604-612.

OSAKABE K, OSAKABE Y, TOKI S (2010). Site-directed mutagenesis in Arabidopsis using custom-designed zinc finger nucleases. Proc Natl Acad Sci USA 107: 12034-12039.

OZAWA K, WAKASA Y, OGO Y, MATSUO K, KAWAHIGASHI H, TAKAIWA F (2012). Development of an efficient agrobacterium-mediated gene targeting system for rice and analysis of rice knockouts lacking granule-bound starch synthase (Waxy) and $\beta 1,2$-xylosyltransferase. Plant Cell Physiol 53: 755-761.

PASZKOWSKI J, BAUR M, BOGUCKI A, POTRYKUS I (1988). Gene targeting in plants. EMBO J 7: 4021-4026.

PETOLINO J F, WORDEN A, CURLEE K, CONNELL J, STRANGE MOYNAHAN T L, LARSEN C, RUSSELL S (2010). Zinc finger nuclease-mediated transgene deletion. Plant Mol Biol 73: 617-628.

PORTEUS M H, BALTIMORE D (2003). Chimeric nucleases stimulate gene targeting in human cells. Science 300: 763

PUCHTA H (1998). Repair of genomic double-strand breaks in somatic plant cells by one-sided invasion of homologous sequences. Plant $J$ 13: 77-78.

PUCHTA H (2003). Towards the ideal GMP: homologous recombination and marker gene excision. J Plant Physiol 160: 743-754.

PUCHTA H, DUJON B, HOHN B (1993). Homologous recombination in plant cells is enhanced by in vivo induction of double strand breaks into DNA by a site-specific endonuclease. Nucleic Acids Res 21: 5034-5040.

RAMALINGAM S, KANDAVELOU K, RAJENDERAN R, CHANDRASEGARAN S (2011). Creating designed zinc-finger nucleases with minimal cytotoxicity. $J$ Mol Biol 405: 630-641.

RAMIREZ C L, FOLEY J E, WRIGHT D A, MULLER-LERCH F, RAHMAN S H, CORNU T I, WINFREY R J, SANDER J D, FU F, TOWNSEND J A, CATHOMEN T, VOYTAS D F, JOUNG J K (2008). Unexpected failure rates for modular assembly of engineered zinc fingers. Nat Methods 5: 374-375.

REISSB, SCHUBERTI, KOPCHEN K, WENDELERE, SCHELLJ, PUCHTAH (2000). RecA stimulates sister chromatid exchange and the fidelity of double-strand break repair, but not gene targeting, in plants transformed by Agrobacterium. Proc Natl Acad Sci USA 97: 3358-3363.

REYON D, KIRKPATRICK J R, SANDER J D, ZHANG F, VOYTAS D F, JOUNG J K, DOBBS D, COFFMAN C R (2011). ZFNGenome: a comprehensive resource for locating zinc finger nuclease target sites in model organisms. BMC Genomics 12:83.

SAKUMAT, HOSOIS, WOLTJENK, SUZUKIKI, KASHIWAGIK, WADAH, OCHIAIH, MIYAMOTO T, KAWAI N, SASAKURA Y, MATSUURA S, OKADA Y, KAWAHARA A, HAYASHI S, YAMAMOTO T (2013). Efficient TALEN construction and evaluation methods for human cell and animal applications. Genes Cells 18: 315-326

SALOMON S, PUCHTA H (1998). Capture of genomic and T-DNA sequences during double-strand break repair in somatic plant cells. EMBO J 17: 6086-6095.

SANDER J D, DAHLBORG E J, GOODWIN M J, CADE L, ZHANG F, CIFUENTES D, CURTIN S J, BLACKBURN J S, THIBODEAU-BEGANNY S, QI Y, PIERICK C J, HOFFMAN E, MAEDER M L, KHAYTER C, REYON D, DOBBS D, LANGENAU D M, STUPAR R M, GIRALDEZ A J, VOYTAS D F, PETERSON R T, YEH J R, JOUNG J K (2011). Selection-free zinc-finger-nuclease engineering by contextdependent assembly (CoDA). Nat Methods 8: 67-69.

SANDER J D, ZABACK P, JOUNG J K, VOYTAS D F, DOBBS D (2007) Zinc Finger Targeter (ZiFiT): an engineered zinc finger/target site design tool. Nucleic Acids Res 35: W599-605.
SHAKED H, MELAMED-BESSUDO C, LEVY A A (2005). High frequency gene targeting in Arabidopsis plants expressing the yeast RAD54 gene. Proc Natl Acad Sci USA 102: 12265-12269.

SHALEV G, SITRIT Y, AVIVI-RAGOLSKI N, LICHTENSTEIN C, LEVY A A (1999) Stimulation of homologous recombination in plants by expression of the bacterial resolvase ruvC. Proc Natl Acad Sci USA 96: 7398-7402.

SHIBOLETH Y, TZFIRA T (2011). Agrobacterium-mediated plant genetic transformation. In Plant biotechnology 2011: basic aspects and agricultural implications (Eds A Altman, M Hasegawa). Elsevier, DOI: 10.1018/B978-0-12-381466-1.00007-9

SHUKLA V K, DOYON Y, MILLER J C, DEKELVER R C, MOEHLE E A, WORDEN S E, MITCHELL J C, ARNOLD N L, GOPALAN S, MENG X, CHOI V M, ROCK $J$ M, WU Y Y, KATIBAH G E, ZHIFANG G, MCCASKILL D, SIMPSON M A BLAKESLEE B, GREENWALT S A, BUTLER H J, HINKLEY S J, ZHANG L, REBAR E J, GREGORY P D, URNOV F D (2009). Precise genome modification in the crop species Zea mays using zinc-finger nucleases. Nature 459: 437-441.

STODDARD B L (2011). Homing endonucleases: from microbial genetic invaders to reagents for targeted DNA modification. Structure 19: 7-15.

TAKASU Y, KOBAYASHI I, BEUMER K, UCHINO K, SEZUTSU H, SAJWAN S, CARROLL D, TAMURA T, ZUROVEC M (2010). Targeted mutagenesis in the silkworm Bombyx moriusing zinc finger nuclease mRNAinjection. Insect Biochem Mol Biol 40: 759-765.

TAYLOR G K, PETRUCCI L H, LAMBERT A R, BAXTER S K, JARJOUR J, STODDARD B L (2012). LAHEDES: The LAGLIDADG homing endonuclease database and engineering server. Nucleic Acids Res 40: W110-W116.

TERADA R, JOHZUKA-HISATOMI Y, SAITOH M, ASAO H, IIDA S (2007). Gene targeting by homologous recombination as a biotechnological tool for rice functional genomics. Plant Physiol 144: 846-856.

TERADA R, URAWA H, INAGAKI Y, TSUGANE K, IIDA S (2002). Efficient gene targeting by homologous recombination in rice. Nat Biotechnol 20: 1030-1034.

THYKJAER T, FINNEMANN J, SCHAUSER L, CHRISTENSEN L, POULSEN C, STOUGAARD J (1997). Gene targeting approaches using positive-negative selection and large flanking regions. Plant Mol Biol 35: 523-530.

TOVARJ, LICHTENSTEINC (1992). Somatic and meiotic chromosomal recombination between inverted duplications in transgenic tobacco plants. Plant Cell4:319-332.

TOVKACH A, ZEEVI V, TZFIRA T (2009). A toolbox and procedural notes for characterizing novel zinc finger nucleases for genome editing in plant cells. Plant $J$ 57: 747-757.

TOVKACH A, ZEEVI V, TZFIRA T (2010). Validation and expression of ZFNs and in plant cells. Methods Mol Cell Biol 649: 315-336.

TOVKACHA, ZEEVIV, TZFIRAT (2011). Expression, purification and characterization of cloning-grade zinc finger nuclease. J Biotechnol 151: 1-8.

TOWNSEND J A, WRIGHT D A, WINFREY R J, FU F, MAEDER M L, JOUNG J K, VOYTAS D F (2009). High-frequency modification of plant genes using engineered zinc-finger nucleases. Nature 459: 442-445.

TZFIRA T, FRANKMEN L, VAIDYA M, CITOVSKY V (2003). Site-specific integration of Agrobacterium tumefaciens T-DNA via double-stranded intermediates. Plant Physiol 133: 1011-1023.

TZFIRA T, LI J, LACROIX B, CITOVSKY V (2004). Agrobacterium T-DNA integration: molecules and models. Trends Genet 20: 375-383.

TZFIRA T, WEINTHAL D, MARTON I, ZEEVI V, ZUKER A, VAINSTEIN A (2012). Genome modifications in plant cells by custom-made restriction enzymes. Plant Biotechnol J 10: 373-389.

UHDE-STONE C, GOR N, CHIN T, HUANG J, LU B (2013). A do-it-yourself protocol for simple transcription activator-like effector assembly. Biol Proced Online 15: 3 .

URNOV F D, MILLER J C, LEE Y L, BEAUSEJOUR C M, ROCK J M, AUGUSTUS S, JAMIESON A C, PORTEUS M H, GREGORY P D, HOLMES M C (2005). Highly efficient endogenous human gene correction using designed zinc-finger nucleases. Nature 435: 646-651.

URNOV F D, REBAR E J, HOLMES M C, ZHANG H S, GREGORY P D (2010). Genome editing with engineered zinc finger nucleases. Nat Rev Genet 11: 636-646.

VAINSTEIN A, MARTON I, ZUKER A, DANZIGER M, TZFIRA T (2011). Permanent genome modifications in plant cells by transient viral vectors. Trends Biotechnol 29: 363-369.

WAKASA Y, HAYASHI S, OZAWA K, TAKAIWA F (2012). Multiple roles of the ER stress sensor IRE1 demonstrated by gene targeting in rice. Sci Rep 2: 944. 
WEINTHAL D M, TAYLOR R A, TZFIRA T (2013). Non-homologous end-joiningmediated gene replacement in plant cells. Plant Physiol 162:390-400.

WEINTHAL D, TOVKACH A, ZEEVI V, TZFIRA T (2010). Genome editing in plant cells by zinc finger nucleases. Trends Plant Sci 15: 308-321.

WOOD A J, LO T W, ZEITLER B, PICKLE C S, RALSTON E J, LEE A H, AMORA R, MILLER J C, LEUNG E, MENG X, ZHANG L, REBAR E J, GREGORY P D, URNOV F D, MEYER B J (2011). Targeted genome editing across species using ZFNs and TALENs. Science 333: 307.

WRIGHT D A, THIBODEAU-BEGANNY S, SANDER J D, WINFREY R J, HIRSH A $S$, EICHTINGER M, FU F, PORTEUS M H, DOBBS D, VOYTAS D F, JOUNG J K (2006). Standardized reagents and protocols for engineering zinc finger nucleases by modular assembly. Nat Protoc 1: 1637-1652.

WRIGHT D A, TOWNSEND J A, WINFREY R J JR, IRWIN P A, RAJAGOPAL J, LONOSKY P M, HALL B D, JONDLE M D, VOYTAS D F (2005). High-frequency homologous recombination in plants mediated by zinc-finger nucleases. Plant J 44: 693-705.

XIAO Y L, PETERSON T (2000). Intrachromosomal homologous recombination in Arabidopsis induced by a maize transposon. Mol Gen Genet 263: 22-29.
XIAOHUI WANG H, VIRET J F, ELDRIDGE A, PERERA R, SIGNER E R, CHIURAZZI M (2001). Positive-negative selection for homologous recombination in Arabidopsis. Gene 272: 249-255.

YAMAUCHIT, JOHZUKA-HISATOMI Y, FUKADA-TANAKAS, TERADAR, NAKAMURA I, IIDA S (2009). Homologous recombination-mediated knock-in targeting of the MET1a gene for a maintenance DNA methyltransferase reproducibly reveals dosage-dependent spatiotemporal gene expression in rice. Plant $J$ 60: 386-396.

YANG M, DJUKANOVIC V, STAGG J, LENDERTS B, BIDNEY D, FALCO S C LYZNIK L A (2009). Targeted mutagenesis in the progeny of maize transgenic plants. Plant Mol Biol 70: 669-679.

ZHANG F, MAEDER M L, UNGER-WALLACE E, HOSHAW J P, REYON D, CHRISTIAN M, LI X, PIERICK C J, DOBBS D, PETERSON T, JOUNG J K, VOYTAS D F (2010). High frequency targeted mutagenesis in Arabidopsis Thaliana using zinc finger nucleases. Proc Natl Acad Sci USA 107: 12028-12033.

ZUO J, NIU Q W, CHUA N H (2000). An estrogen receptor-based transactivator XVE mediates highly inducible gene expression in transgenic plants. PlantJ24:265-273. 


\section{Further Related Reading, published previously in the Int. J. Dev. Biol.}

DNA methylation establishment during oocyte growth: mechanisms and significance Shin-Ichi Tomizawa, Joanna Nowacka-Woszuk and Gavin Kelsey

Int. J. Dev. Biol. (2012) 56: 867-875

http://dx.doi.org/10.1387/ijdb.120152gk

Preface to the "Epigenetics \& Development" Special Issue

Saadi Khochbin and Stefan Nonchev

Int. J. Dev. Biol. (2009) 53: 189-190

http://dx.doi.org/10.1387/ijdb.092909sk

Chromatin remodeling in plant development

José A. Jarillo, Manuel Piñeiro, Pilar Cubas and José M. Martínez-Zapater

Int. J. Dev. Biol. (2009) 53: 1581-1596

http://dx.doi.org/10.1387/ijdb.072460jj

Equivalent genetic regulatory networks in different contexts recover contrasting spatial cell patterns that resemble those in Arabidopsis root and leaf epidermis: a dynamic model

Mariana Benítez, Carlos Espinosa-Soto, Pablo Padilla-Longoria, José Díaz and Elena R. Alvarez-Buylla

Int. J. Dev. Biol. (2007) 51: 139-155

http://dx.doi.org/10.1387/ijdb.062183mb

Genetic control of floral size and proportions

Julia Weiss, Luciana Delgado-Benarroch and Marcos Egea-Cortines

Int. J. Dev. Biol. (2005) 49: 513-525

http://dx.doi.org/10.1387/ijdb.051998jw

5 yr ISI Impact Factor $(2011)=2.959$
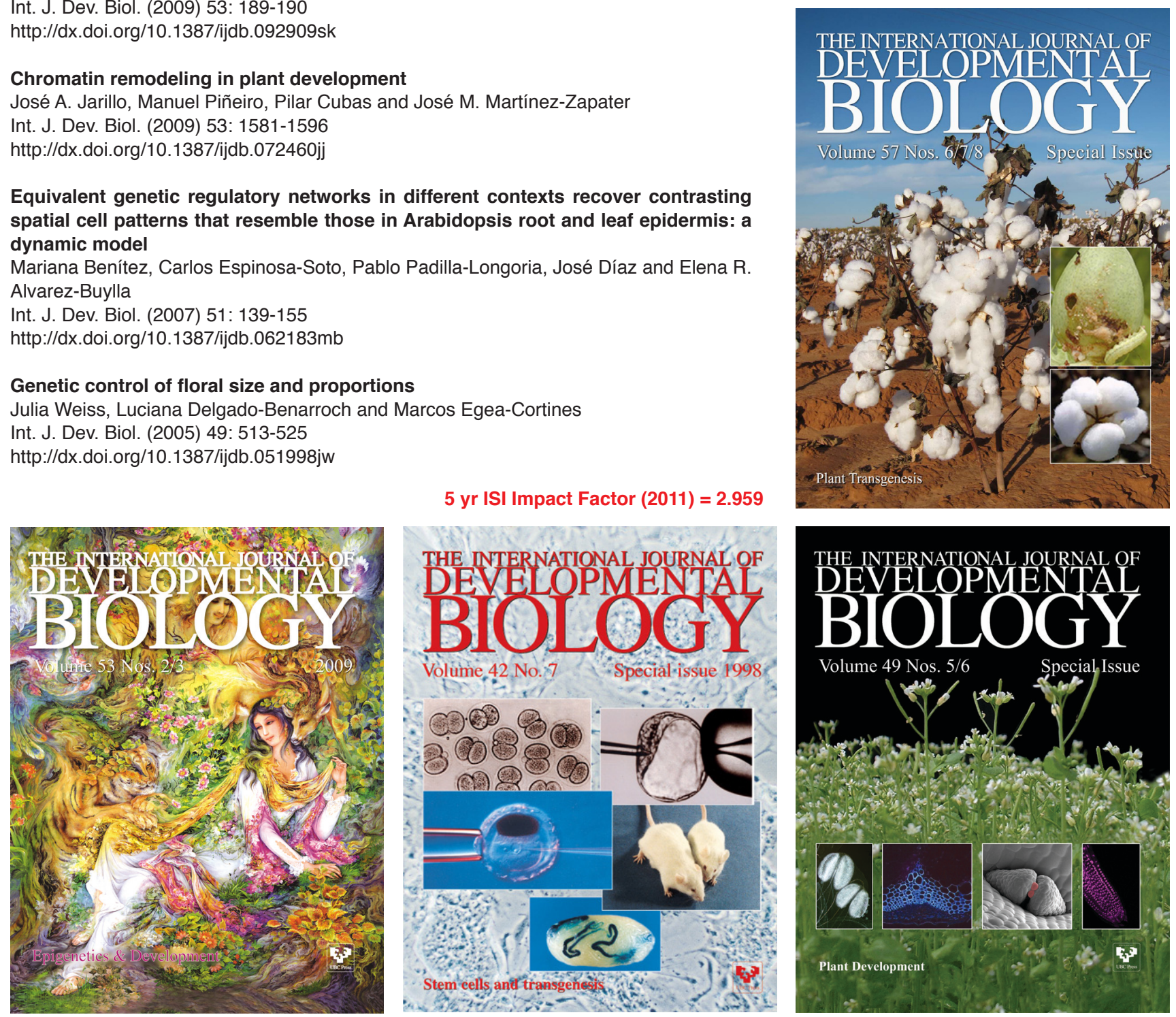